\title{
Survival Strategies of Marketers in the Nigerian Banking Industry
}

\section{Edwin Anyim*}

School of Management Science, National Open University of Nigeria, Lagos, Nigeria

\begin{abstract}
The importance of marketing strategies in the Banking Industries cannot be over emphasized because it is an important aim of banking sector. Due to competition within and outside the country, these has brought about globalization and an improvement in customer awareness, and have made banks to use marketing as an important tool to increase returns, improve the productivity of the Nigerian banking system and also compete effectively.

This study is set out to investigate the survival strategies of marketers in the Nigerian banking industry with specific focus on deposit money banks. The data gathered were analyzed by using frequency and percentages. The hypothesis formulated for the study was tested by the use of the chi-square method to arrive at the research result. Findings revealed that marketing strategy development are important for continuing growth and survival of business organization in this volatile Nigerian marketing environment.
\end{abstract}

Keywords: Survival; Strategy; Marketing; Deposit; Money bank

\section{Introduction}

Marketing strategy is used in all the sectors of the economy, most especially in the banking sector. Marketing strategy has been the backbone of many organization whether as a short term goal or as a long term success [1]. Strategy is very important in any banking industry in Nigeria today because of the nature of marketing environment. Every banking institution must use marketing strategy to develop a competitive advantage.

The essence of marketing strategy in any organization is to help in providing solutions to the problems encountered in the marketing of their services [2].

The advantages in marketing of banking services could be attained when an organization can determine the needs and wants of the customer and directs its marketing effort towards those needs and wants [3].

This research work is designed to examine the role and contribution of strategic marketing to performance in the banking industry.

\section{Literature Review}

Marketing has been diligently given definitions and practically every author has its own interpretation of the concept. However, the definition most commonly used as a reference is that of the American Marketing Association (AMA). The current definition of AMA is the following.

Marketing is an organizational function and a set of process for creating, communication and delivering value to customers and for managing customer relationships in ways that benefit the organization and its stakeholders.

Hooley et al. [4] in turn, defined marketing as the process of profitably matching organizational capabilities to the requirements of chosen customers.

Kotler [5] defined strategy as "the board principles by which the business units expect to achieve its marketing objectives in a target market. It consists of basic decisions on total marketing expenditure, marketing mix and marketing allocations".

Thus, marketing strategy is a set of objectives, policies and rules that guide the organizations marketing effort overtime. This involves response to changing environment and competitive conditions employing all resources of an organizational towards attaining the desired goals in terms of sales, pricing and distribution.

According to Sobowale [6] strategy can be looked into from another angle, which is the deployment of human and financial resources against competitions in the pursuit of goals and objectives determined by the leaders of business enterprises, organization or even a nation.

Charles and Gareth [7] define strategy as a specific pattern of decisions and actions that managers take to achieve an organization's goal.

Nigeria Financial Review [8] also defined strategy as a proposed action intended to have a far reaching effect on the entity's ability to achieve its objective [9]. It is a blue print to every organization. Strategy marketing process is thus a managerial process by analyzing market opportunities and choosing marketing position, programs and controls that create and support viable business that serve the company's purpose and goals [10]

Developing marketing strategy involves a realistic assessment of the weighty of an organization's strength and weakness against opportunities and risks that exist in the market place [11-13]. There are three activities that a company needs to complete in order to develop a marketing strategy

1. Determine the desired market position

2. Select a growth strategy

3. Choose differentiated, undifferentiated, or concentrated marketing.

In concluding this section, it is worth emphasizing that the concept

*Corresponding author: Anyim E, School of Management Science, National Open University of Nigeria, Lagos, Nigeria, Tel: +234 807507 4911; E-mail: akachiedwin@yahoo.com

Received May 18, 2017; Accepted June 22, 2018; Published June 29, 2018

Citation: Anyim E (2018) Survival Strategies of Marketers in the Nigerian Banking Industry. Bus Eco J 9: 359. doi: 10.4172/2151-6219.1000359

Copyright: (C) 2018 Anyim E. This is an open-access article distributed under the terms of the Creative Commons Attribution License, which permits unrestricted use, distribution, and reproduction in any medium, provided the original author and source are credited. 
of strategy has a dynamic component; it implies effectiveness and efficiency, but it also implies responsiveness in developing awareness to environmental change and identifying appropriate and effective reaction to that change.

\section{Methodology}

This study focuses on two banks as case study. The sample size comprises of one hundred (100) personnel of the case study. A total of one hundred questionnaire were administered out of which eighty (80) were returned. This represents $80 \%$ returned rate of administered questionnaires [14].

The researcher utilized both primary and secondary data. The primary source includes the administration of questionnaires and interview with the staff of the selected banks the questionnaires were administered to the personnel of banks that carry out marketing functions [15].

\section{Results and Discussion}

This section presents the results of the data analysis.

The table above shows that from the 80 respondents, 55 (68.75\%) were male while $25(31.25 \%)$ were female. This is an indication that males dominate the operation of banks in Nigeria. The table also indicates that respondents between the ages of 25-29 years were 40 $(50 \%)$ while those between the ages of $30-50$ were $40(50 \%)$. This is an indication that their information is reliable and dependable (Table 1).
More also, 18 (22.505) of the respondents are single while 62 (77.50\%) are married. As revealed from the table, 40(50\%) of the respondents have spent between 1 to 5 years in the bank while 25 (32.25\%) have spent between $10-20$ years; only 15 (18.75\%) of the respondents spent 10 years and above.

As regards how banks increase profit as well as sustain growth through marketing about 53 (66.25\%) strongly agreed, 24 (30\%) agreed, 3 (3.75\%) of the respondents were undecided and none of the respondents strongly disagreed.

With respect to of management develop different product for marketing plans for different segments of the market, about $48(60 \%)$ of the respondents strongly agreed, $25(31.25 \%)$ agreed, $5(6.25 \%)$ of the respondents were undecided and 2 (2.5\%) disagreed, none of the respondents strongly disagreed. This shows that management develop different product for marketing plans using different segment of the market.

The table also shows that $30(37.5 \%)$ of the respondents strongly agreed that pro-active marketing is far better than reactive marketing $25(31.25 \%)$ agreed, $20(25 \%)$ of the respondents were undecided, 3 (3.75\%) disagreed while 2 (2.5\%) strongly disagreed.

\section{Testing of the Hypothesis}

$\mathrm{H}_{0}$ : Reactive marketing is far better than pro-active marketing

$\mathrm{H}_{\mathrm{i}}$ : Proactive marketing is far better than reactive marketing

\begin{tabular}{|c|c|c|c|}
\hline \multicolumn{4}{|c|}{ Section A } \\
\hline \multicolumn{2}{|l|}{ Personal data } & Number & Percentage (\%) \\
\hline \multirow[t]{2}{*}{ Sex } & Male & 55 & 68.75 \\
\hline & Female & 25 & 31.25 \\
\hline \multirow[t]{3}{*}{ Age } & $25-29$ years & 40 & 50 \\
\hline & $30-49$ years & 24 & 30 \\
\hline & 50 years above & 16 & 20 \\
\hline \multirow[t]{2}{*}{ Marital Status } & Single & 18 & 22.5 \\
\hline & Married & 62 & 77.5 \\
\hline \multirow[t]{3}{*}{ Length of service } & $1-5$ years & 40 & 50 \\
\hline & $10-20$ years & 25 & 32.25 \\
\hline & 21 years above & 15 & 18.75 \\
\hline \multicolumn{4}{|c|}{ Section B } \\
\hline \multirow[t]{7}{*}{ Banks increase profit as well as sustain growth through marketing } & Response variable & Frequency & Percentage \\
\hline & Strongly agreed & 53 & 66.25 \\
\hline & Agreed & 24 & 30 \\
\hline & Undecided & 3 & 3.75 \\
\hline & Disagreed & - & - \\
\hline & Strongly disagreed & - & - \\
\hline & Total & 80 & 100 \\
\hline \multirow{7}{*}{$\begin{array}{l}\text { Does management develop different product and marketing plans for } \\
\text { different segments of the market }\end{array}$} & Response variable & Frequency & Percentage (\%) \\
\hline & Strongly agreed & 48 & 60 \\
\hline & Agreed & 25 & 31.25 \\
\hline & Undecided & 5 & 6.25 \\
\hline & Disagreed & 2 & 2.25 \\
\hline & Strongly disagreed & - & - \\
\hline & Total & 80 & 100 \\
\hline \multirow{7}{*}{$\begin{array}{l}\text { Pro-active marketing is far better than reaction marketing in a } \\
\text { dynamic banking environment }\end{array}$} & Response variable & Frequency & Percentage (\%) \\
\hline & Strongly agreed & 30 & 37.5 \\
\hline & Agreed & 25 & 31.25 \\
\hline & Undecided & 20 & 25 \\
\hline & Disagreed & 3 & 3.75 \\
\hline & Strongly disagreed & 2 & 2.5 \\
\hline & Total & 80 & 100 \\
\hline
\end{tabular}

Source: Field survey 2018.

Table 1: Distribution of responses on personal data of respondents. 
Using the contingency chi-square test, we therefore reject the null hypothesis since $\mathrm{X}_{c}^{2}>\mathrm{X}^{2} 0.05$ i.e., $64.87>9.488$ and accept the alternative hypothesis $\left(\mathrm{H}_{\mathrm{i}}\right)$ at 0.95 level of significance.

$\mathrm{X}_{\mathrm{c}}^{2}=$ computed value and $\mathrm{X}_{\mathrm{t}}^{2}$ 0.05-table value.

The policy implication of this decision is that pro-active marketing is far better than reactive marketing in the banking industry. Henceforth, the continuing existence and survival of these banks in the face of completion is based on the different kinds of marketing strategies being used by them.

\section{Conclusion}

In this area of an ever changing and competitive global economic environment, especially now at the current economic approach of the government is moving towards openness and enthronement of a market based economic system and with globalization being the major force that enhances growth and development, Nigeria banks cannot afford to be left behind. The researcher strongly advocates that banks should continuously review, redesign, refocus and re-engineer their core business process on a period basis to ensure that they are competitively relevant in the global market.

This is why this study undertakes the detail out the processes, methods and gains of adopting survival strategies and restructuring and its roles in baking sector.

It is my belief that with a good implementation of the approaches and recommendation here in the issues of distress; inefficiency and its associated problems will be a thing of the past.

Nigeria banks will be the rank of global banks rating while playing their lending role in resource mobilization, ushering in an era of effective payment system and providing the necessary impetus for economic growth.

\section{References}

1. Nashiru ZM (2018) Exploring the Guiding Principle or Philosophy of Knowledge
Management $(\mathrm{Km})$ Implementation by the Banking Leaders at the Central Bank of Ghana. J Entrepren Organiz Manag 7: 231.

2. Njebi NK (2018) Effects of the Banking (Amendment) Act of 2016 on the Kenyan Banking Sector. J Bus Fin Aff 7:310.

3. Ceesay LB (2017 Consumer-Band Association: Determinants of Consumer Bank Switching Intention, Case of the Gambia Retail Banking Sector. J Bus Fin Aff 6:295.

4. Hooley G, Cox T, Fahy J, Shipley D, Berac J, et al., (1999) Marketing capabilities and Firm performance: A Hierarchical model. J Market Focused Manage 4: 259-278.

5. Kotler P (1996) Marketng Management: Analysis, Planning, Implementation and Control Prentice. Hal Int. Inc. New Jersey, USA, pp: 91-92.

6. Sobowale D (1997) Developing Indigenous Marketing Strategy for Competitive Advantages. J Nigerian I Manage 33: 85.

7. Charles WL, Gareth RJ (1998) Strategic Management Theory: An integrated Approach, Houghton Mifflin Company, Boston, pp: 2-30.

8. Nigeria Financial Review (1998)

9. Hazrati S (2017) Psychological Contract Breach and Affective Commitment in Banking Sector:The Mediation Effect of Psychological Contract Violation and Trust. Arab J Bus Manage Rev 7:320.

10. Dwomoh G, Frempong EO (2017) Factors Influencing Employees? Retention in the Banking Industry of Ghana. Review Pub Administration Manag 5: 223.

11. Ferhi A (2017) Credit Risk and Banking Stability: A Comparative Study between Islamic and Conventional Banks. Intel Prop Rights 5: 193.

12. Zaidi AN (2017) Customer Knowledge Management (CKM) as a Predictor of Innovation Capability with the Moderating Role of Organizational Structure: A Study of the Banking Sector of Pakistan. Arab J Bus Manage Rev 7:307.

13. Somal HK (2017) Big Data \& Analytics: Tackling Business Challenges in Banking Industry. Bus Eco J 8: 305.

14. Sanjeepan N (2017) Strategic Analysis and Strategic Planning for Commercial Banking (An Analysis based a Commercial Bank operating in Sri Lanka). Int J Econ Manag Sci 6: 418.

15. Al Ghammari KA, Ahmed EM (2017) Customers' Switching Intention in Oman's Banking Industry. J Bus Fin Aff 6:270. 